Acta vet. scand. $1970,11,1-15$.

From the Institute for the Application of Nuclear Energy in Agriculture, Veterinary Medicine and Forestry, Zemun, Yugoslavia.*

\title{
SOME EFFECTS OF PROTEIN DEFICIENCY IN YOUNG GROWING PIGS \\ II. BLOOD PLASMA FREE AMINO ACIDS ${ }^{\star \star}$
}

\author{
By \\ M. Čuperlović and D. Stošić
}

The amino acid pattern induced by lack of dietary protein is very different from that which follows total starvation, when insufficiency of energy is the primary factor. Thus, according to Holt et al. (1968), the basic effects of protein deficiency on blood free amino acids are a decrease in concentration of most essential amino acids, especially those with branched carbon chains, and a resistance to change of the non-essential amino acids except for tyrosine, arginine, citrulline and $\alpha$-amino-n-butyric acid. The characteristic alterations which follow total starvation are an elevation of most essential amino acid concentrations which particularly affects valine, leucine, isoleucine and threonine, decreases in the levels of some non-essential amino acids and a very high concentration of plasma urea ( $\breve{C u p e r l o v i c ́ ~ e t ~ a l . ~ 1968) . ~}$

However, the many attempts to use these alterations in the free amino acid patterns to assess the severity of nutritional deficiencies and the nature of the limiting dietary component have been of limited significance (Whitehead 1965, Widdowson

* In collaboration with the Department of Physiology, Endocrinology and Bloodgrouping, Royal Veterinary and Agricultural University, Copenhagen, Denmark.

* * This investigation was supported in part by the Federal and Republic Fund for Coordination of Scientific Investigations, SFR Yugoslavia and by the United States Department of Agriculture, USA, Grant Contract no. PL 480. 
$\&$ Whitehead 1966). Differences are especially prominent during rehabilitation from protein deficiency when the free amino acid pattern becomes normal before the general state of the organism can be considered as recovered (Saunders et al. 1967). Moreover, different combinations of protein malnutrition and energy deficiency make the whole picture more complicated.

In this connection we have attempted to investigate changes in the free amino acids in the blood plasma of pigs during long term protein deficiency and to compare it with the pattern found during total starvation. The concentrations of free amino acids in the blood plasma during rehabilitation have also been followed.

\section{MATERIALS AND METHODS}

The treatment of the animals and diets have been described in a previous paper (Nikolić et al. 1969).

Blood samples were collected every fortnight during the experimental period from the jugular vein after a $16 \mathrm{hr}$. fast into cooled heparinized tubes. After separation by centrifugation, the plasmas of pigs from the same group were pooled and deproteinated according to Stein \& Moore (1954). The concentrations of the free amino acids and urea were determined on an automatic amino acid analyser (Spinco Beckman Model 120 B).

The amino acid compositions of both the diets employed were determined after acid hydrolysis (Lindquist 1966).

\section{RESULTS}

The amino acid composition of the control semisynthetic diet containing milk powder (Table 1) satisfied the requirements of growing pigs. In the non-protein semisynthetic diet, amino acid levels were very low and in some cases almost below the limits of detection. Most of the nitrogen in the diet was present in the hydroxyproline fraction.

\section{Free amino acids in the blood plasma}

a) Control group. Levels of all the essential amino acids, except for lysine, in the blood plasma of Group A, which received the milk protein containing diet during the whole experimental period, were lower at the first determination than at any time later (Table 2). In the non-essential amino acid group 
Table 1. Content of free amino acids in the semisynthetic diets with and without milk protein supplement.

\begin{tabular}{|c|c|c|c|c|}
\hline \multirow{2}{*}{ Amino acids } & \multicolumn{2}{|c|}{ Mixture with protein } & \multicolumn{2}{|c|}{ Mixture without protein } \\
\hline & $\begin{array}{l}\mathrm{g} / 100 \mathrm{~g} \\
\text { dry matter }\end{array}$ & $\begin{array}{l}\mathrm{g} / 100 \mathrm{~g} \\
\text { crude protein }\end{array}$ & $\begin{array}{c}\mathrm{g} / 100 \mathrm{~g} \\
\text { dry matter }\end{array}$ & $\begin{array}{l}\mathrm{g} / 100 \mathrm{~g} \\
\text { crude protein }\end{array}$ \\
\hline lysine & 0.97 & 6.40 & 0.013 & 1.20 \\
\hline histidine & 0.34 & 2.29 & 0.098 & 8.90 \\
\hline arginine & 0.48 & 3.26 & + & + \\
\hline aspartic acid & 0.98 & 6,58 & - & - \\
\hline threonine & 0.59 & 3.92 & - & - \\
\hline serine & 0.71 & 4.80 & 0.076 & 6.90 \\
\hline glutamic acid & 2.85 & 19.14 & 0.084 & 7.70 \\
\hline proline & 1.17 & 7.83 & + & + \\
\hline glycine & 0.25 & 1.69 & 0.022 & 2.00 \\
\hline alanine & 0.43 & 2.88 & 0.030 & 2.70 \\
\hline cystine & & 1.10 & 0.020 & 1.80 \\
\hline valine & & 5.20 & 0.030 & 2.70 \\
\hline methionine & 0.28 & 1.92 & 0.004 & 0.40 \\
\hline isoleucine & 0.68 & 4.55 & 0.013 & 1.20 \\
\hline leucine & 1.22 & 8.21 & 0.043 & 3.90 \\
\hline tyrosine & 0.52 & 3.52 & 0.005 & 0.50 \\
\hline phenylalanine & 0.60 & 4.07 & 0.010 & 0.90 \\
\hline hydroxyproline & 1.97 & 12.03 & 0.662 & 60.00 \\
\hline proteins & $14.88 \%$ & & $1.10 \%$ & \\
\hline moisture & $6.95 \%$ & & $9.33 \%$ & \\
\hline
\end{tabular}

this effect was less noticeable (serine, proline, citrulline and tyrosine) or completely absent (arginine and ornithine). The levels of glutamic acid, glycine and alanine were higher than later. From the 14th day to the end of the experimental period the concentrations of individual amino acids varied little, so that the ratio between the concentrations of essential and nonessential amino acids after starting at 0.41 remained almost constant above 0.7 until the end of the investigation. Fig. 1 shows the plasma aminogram at the time the different groups were given the different diets, after 42 days and at the end of the experiment (84 days). Zimmermann-Telschow (1965) found a similar increase in the amino acids in the blood plasma of men consuming a milk protein containing diet.

b) Protein deprived and rehabilitated group. The concentrations of many free essential amino acids in the blood plasma of 
T a b le 2. Free amino acids in the blood plasma of pigs fed the semisynthetic diet containing skimmed milk powder (Group A).

\begin{tabular}{|c|c|c|c|c|c|c|c|}
\hline \multirow{2}{*}{ Amino acids } & \multicolumn{7}{|c|}{ Duration of experiment (days) } \\
\hline & $\mathbf{0}$ & 14 & 29 & 42 & 56 & 70 & 84 \\
\hline threonine & $0.94^{*}$ & 1.98 & 1.86 & 1.73 & 1.86 & 1.96 & 1.73 \\
\hline valine & 2.91 & 3.79 & 4.41 & 3.87 & 4.07 & 4.41 & 3.62 \\
\hline methionine & 0.29 & 0.42 & 0.45 & 0.37 & 0.45 & 0.66 & 0.48 \\
\hline isoleucine & 1.08 & 1.56 & 1.67 & 1.54 & 1.41 & 1.72 & 1.46 \\
\hline leucine & 1.47 & 2.10 & 2.28 & 2.14 & 2.08 & 2.36 & 2.05 \\
\hline phenylalanine & 0.70 & 1.01 & 0.99 & 1.15 & 1.01 & 1.04 & 0.91 \\
\hline lysine & 2.38 & 2.35 & 2.09 & 2.12 & 2.73 & 2.68 & 2.38 \\
\hline histidine & 0.47 & 0.92 & 1.03 & 0.90 & 1.14 & 0.80 & 1.26 \\
\hline $\begin{array}{l}\text { total essential amino } \\
\text { acids }\end{array}$ & 10.24 & 14.13 & 14.78 & 13.82 & 14.75 & 15.63 & 13.89 \\
\hline serine & 1.44 & 1.68 & 1.72 & 1.63 & 1.64 & 2.03 & 2.15 \\
\hline proline & 1.81 & 2.22 & 2.25 & 2.04 & 2.26 & 2.17 & 2.39 \\
\hline glutamic acid & 3.21 & 1.81 & 1.42 & 1.30 & 1.61 & 1.97 & 1.27 \\
\hline citrulline & 1.27 & 1.57 & 1.46 & 1.37 & 1.70 & 1.77 & 1.58 \\
\hline glycine & 6.59 & 5.68 & 5.05 & 5.00 & 5.39 & 6.70 & 5.16 \\
\hline alanine & 3.83 & 2.26 & 2.29 & 2.54 & 2.65 & 3.67 & 2.30 \\
\hline tyrosine & 1.09 & 1.42 & 1.32 & 1.44 & 1.46 & 1.48 & 1.27 \\
\hline ornithine & 1.34 & 1.97 & 2.02 & 1.05 & 0.95 & 1.27 & 0.71 \\
\hline arginine & 1.32 & 1.07 & 1.25 & 1.27 & 1.21 & 0.97 & 1.84 \\
\hline $\begin{array}{l}\text { total non-essential } \\
\text { amino acids }\end{array}$ & 21.90 & 19.68 & 18.78 & 17.64 & 18.87 & 22.03 & 18.67 \\
\hline $\begin{array}{l}\text { ratio of essential to non } \\
\text { essential amino acids }\end{array}$ & 0.47 & 0.71 & 0.78 & 0.72 & 0.78 & 0.71 & 0.74 \\
\hline
\end{tabular}

* $\mathrm{mg} / 100 \mathrm{ml}$ plasma.

the pigs which received the protein deficient diet followed by a diet containing $15 \%$ of milk protein fell continuously (Group B) up to the 42nd day. However, the concentration of lysine was elevated during the first month of protein depletion and only fell below initial levels after 42 days. The levels of phenylalanine, histidine and methionine increased to control levels during the first fortnight and even after 42 days were still higher than the initial concentrations.

The concentrations of the non-essential amino acids were affected by protein deficiency to a smaller extent. Tyrosine, ornithine and glutamic acid showed the greatest reductions. The levels of arginine, glycine and alanine increased during the first 


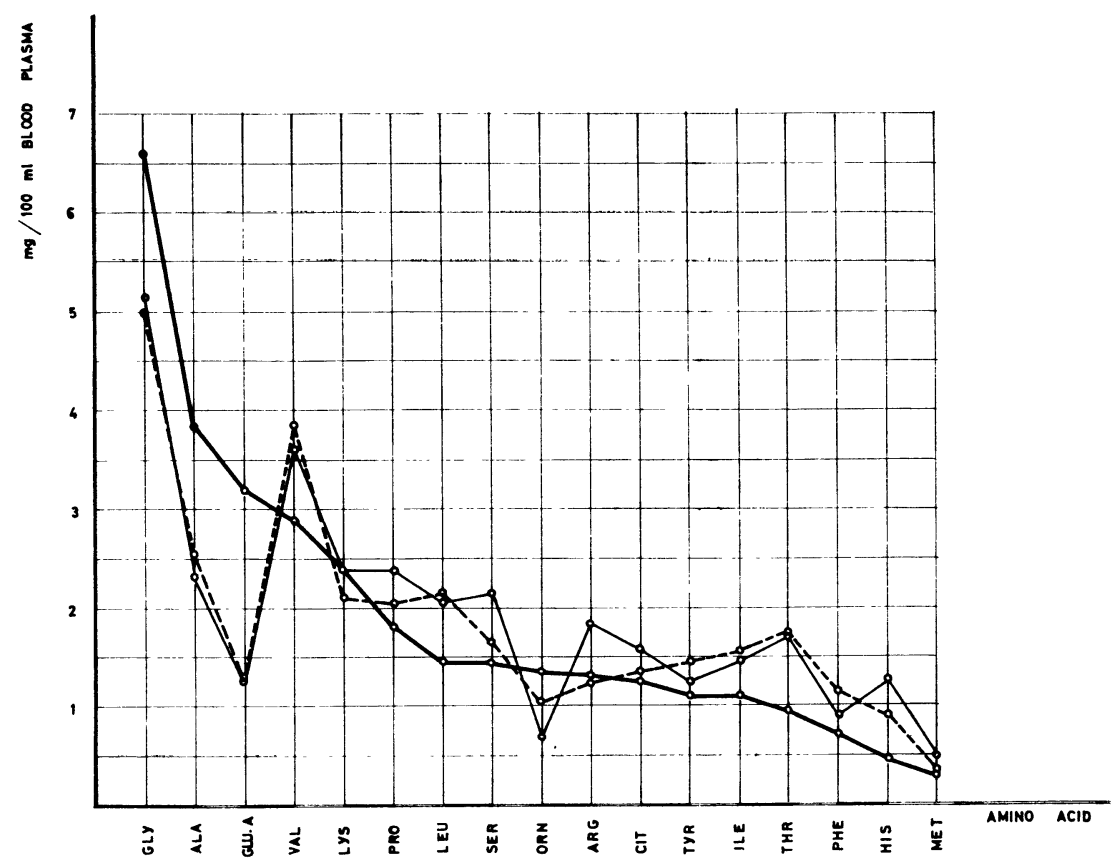

Fig u re 1. Free amino acids in the blood plasma of pigs from the control group at the beginning of the experiment $(0-0)$; after 42 days $(0 \ldots \ldots . . . . .0)$; and after 84 days $\left(0 \_0\right)$ of refeeding with a semisynthetic diet supplemented with skimmed milk powder.

few weeks of protein deficiency and then decreased below the initial levels. These changes resulted in an almost constant amino acid ratio during this period.

The change of diet was followed by a continuous increase in the concentrations of free non-essential and essential amino acids except for phenylalanine and histidine which decreased at first. After two weeks, serine, glutamic acid, alanine and ornithine showed higher levels than in control pigs. By the end of the investigation the levels of all amino acids and the amino acid ratio were near to control values. Fig. 2 shows the plasma aminogram of these pigs at three characteristic points of the experiment.

c) Protein deprived group. During the first 42 day period the changes in the free amino acid concentrations of the protein deprived Group $\mathrm{C}$ were similar to those of Group B. Since differences between the pigs of this group became apparent, the 
T a b l e 3. Free amino acids in the blood plasma of pigs from group B which received a diet deficient in protein for 42 days and then food containing skimmed milk powder.

\begin{tabular}{|c|c|c|c|c|c|c|c|}
\hline \multirow{2}{*}{ Amino acids } & \multicolumn{3}{|c|}{ Nonprotein mixture } & \multicolumn{4}{|c|}{ Mixture containing milk protein } \\
\hline & $0^{\star}$ & 14 & 29 & 42 & 56 & 70 & 84 \\
\hline threonine & $1.18^{\star \star}$ & 0.90 & 0.80 & 0.47 & 1.56 & 1.41 & 1.71 \\
\hline valine & 3.00 & 1.51 & 1.81 & 1.31 & 2.71 & 2.64 & 3.14 \\
\hline methionine & 0.32 & 0.60 & 0.61 & 0.38 & 0.25 & 0.33 & 0.47 \\
\hline isoleucine & 1.24 & 0.89 & 1.17 & 0.84 & 0.97 & 1.26 & 1.78 \\
\hline leucine & 1.66 & 1.37 & 1.10 & 0.84 & 1.29 & 1.47 & 1.97 \\
\hline phenylalanine & 0.66 & 1.08 & 0.96 & 0.95 & 0.49 & 0.37 & 1.14 \\
\hline lysine & 2.03 & 2.95 & 2.45 & 1.44 & 2.05 & 1.49 & 1.55 \\
\hline histidine & 0.42 & 1.09 & 1.27 & 0.80 & 0.33 & 0.49 & 0.71 \\
\hline $\begin{array}{l}\text { total essential } \\
\text { amino acids }\end{array}$ & 10.51 & 10.39 & 10.17 & 7.03 & 9.65 & 9.46 & 12.47 \\
\hline serine & 1.55 & 1.95 & 1.71 & 1.23 & 2.44 & 2.14 & 1.98 \\
\hline proline & $<2.26$ & 1.72 & 1.99 & 1.90 & 2.00 & 1.49 & 1.52 \\
\hline glutamic acid & 3.19 & 1.69 & 1.14 & 1.19 & 2.58 & 3.02 & 1.86 \\
\hline citrulline & 1.01 & 0.84 & 1.08 & 0.78 & 1.17 & 1.13 & 1.41 \\
\hline glycine & 6.12 & 7.15 & 6.32 & 3.98 & 5.10 & 5.24 & 4.32 \\
\hline alanine & 3.47 & 3.71 & 3.30 & 2.53 & 4.06 & 2.68 & 2.52 \\
\hline tyrosine & 1.06 & 0.59 & 0.65 & 0.70 & 0.83 & 0.97 & 1.27 \\
\hline ornithine & 1.21 & 0.69 & 1.03 & 0.41 & 1.24 & 0.90 & 0.91 \\
\hline arginine & 1.13 & 1.50 & 1.03 & 0.47 & 0.80 & 1.17 & 1.35 \\
\hline amino acids & 21.00 & 19.79 & 18.25 & 13.19 & 20.22 & 18.74 & 17.14 \\
\hline
\end{tabular}

ratio of essential to non-

\begin{tabular}{llllllll} 
essential amino acids & 0.50 & 0.52 & 0.55 & 0.52 & 0.48 & 0.50 & 0.73 \\
\hline
\end{tabular}

* Duration of experiment (days).

* $\mathrm{mg} / 100 \mathrm{ml}$ plasma.

plasmas were assayed individually. The lowest concentrations of essential and particularly non-essential amino acids were found in pig no. 13, which was killed in a moribund state after 70 days of protein deprivation. In the other two pigs most free amino acids showed minimum levels at this time. The animals then consumed very little food particularly during the last four days of the investigation. The analysis of the last plasma sample showed increased concentrations of threonine, valine, isoleucine, leucine and lysine, while the concentrations of non-essential amino acids decreased even more during this last fortnight. Thus, the amino acid ratio increased above control levels. The plasma aminogram 


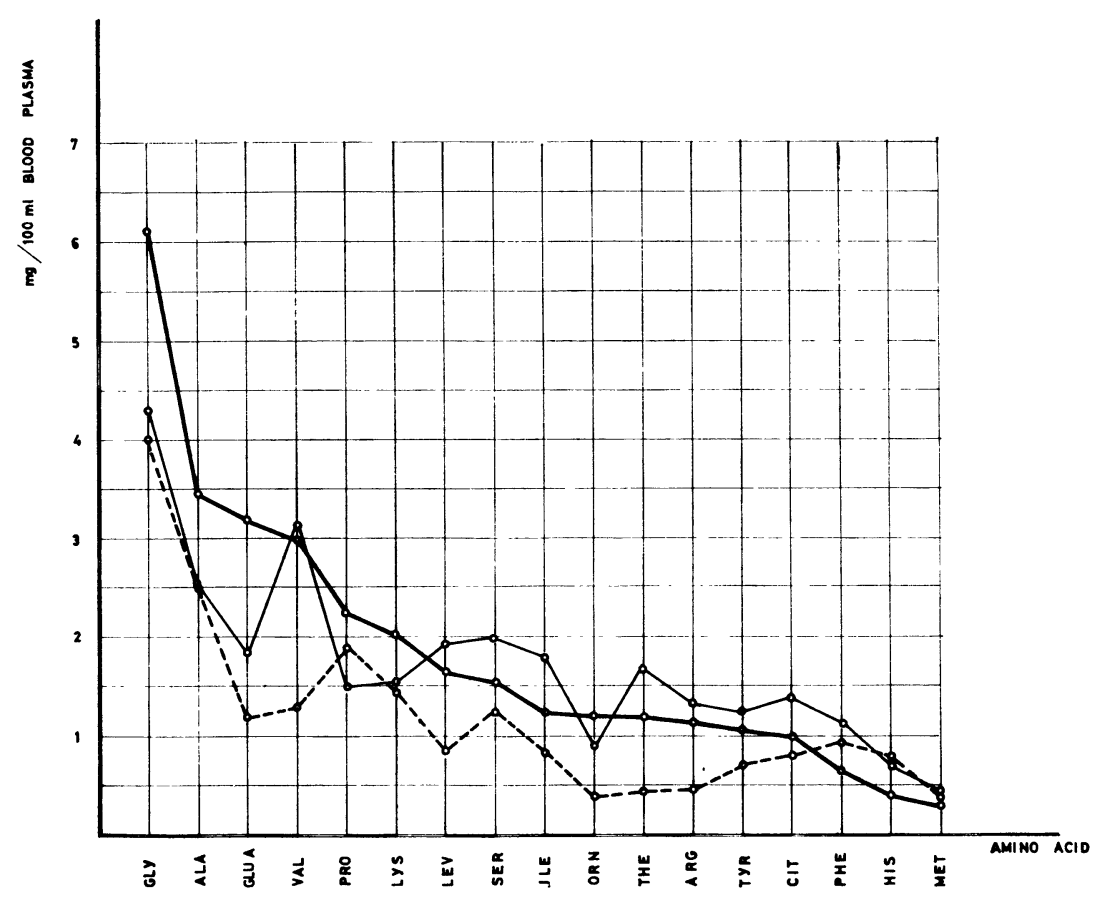

$\mathrm{Fig} \mathrm{u} \mathrm{r}$ 2. Concentrations of free amino acids in the blood plasmas of pigs during protein deficiency and rehabilitation (cf. Fig. 1).

at the beginning of the experiment, after 42 days and 84 days of protein deprivation is given in Figure 3.

d) Totally starved group. The concentrations of essential amino acids increased during total starvation while the concentrations of most non-essential amino acids decreased (Table 5). The ratio between the two types of amino acids increased from 0.50 to 1.38 .

e) Plasma levels of urea. The control pigs (Group A) showed a sharp increase in plasma urea during the first fortnight of the experimental period (Table 6 ). Thereafter the rate of increase was small but definite. During protein deprivation the levels of blood urea decreased rapidly to very low amounts. By the end of the experiment the urea levels of the rehabilitated pigs had reached control regions. An increase in plasma urea concentration was noted in Group $\mathrm{C}$ during the last fortnight of the experimental period. Total starvation was followed by a very large increase in blood urea concentration. 


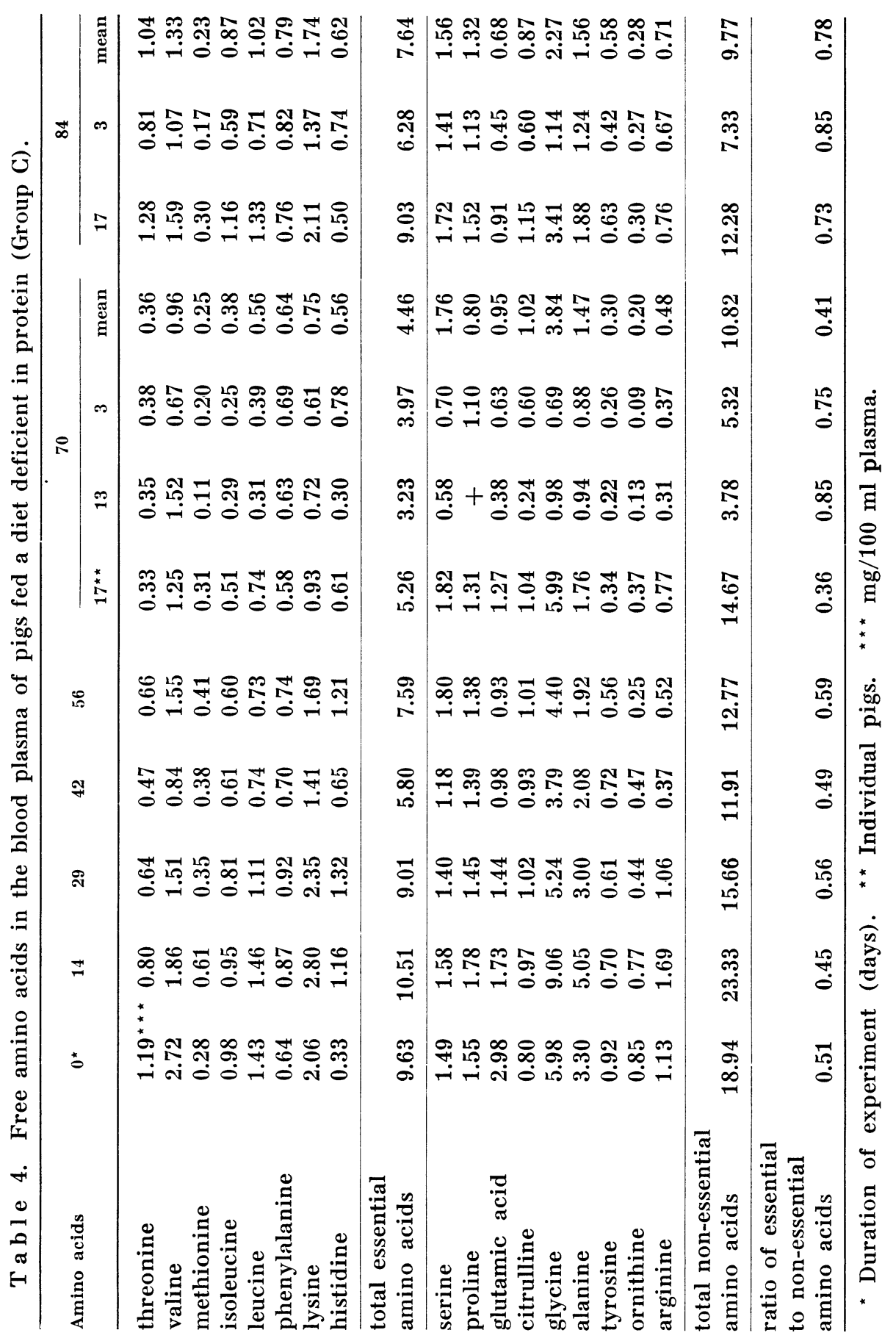




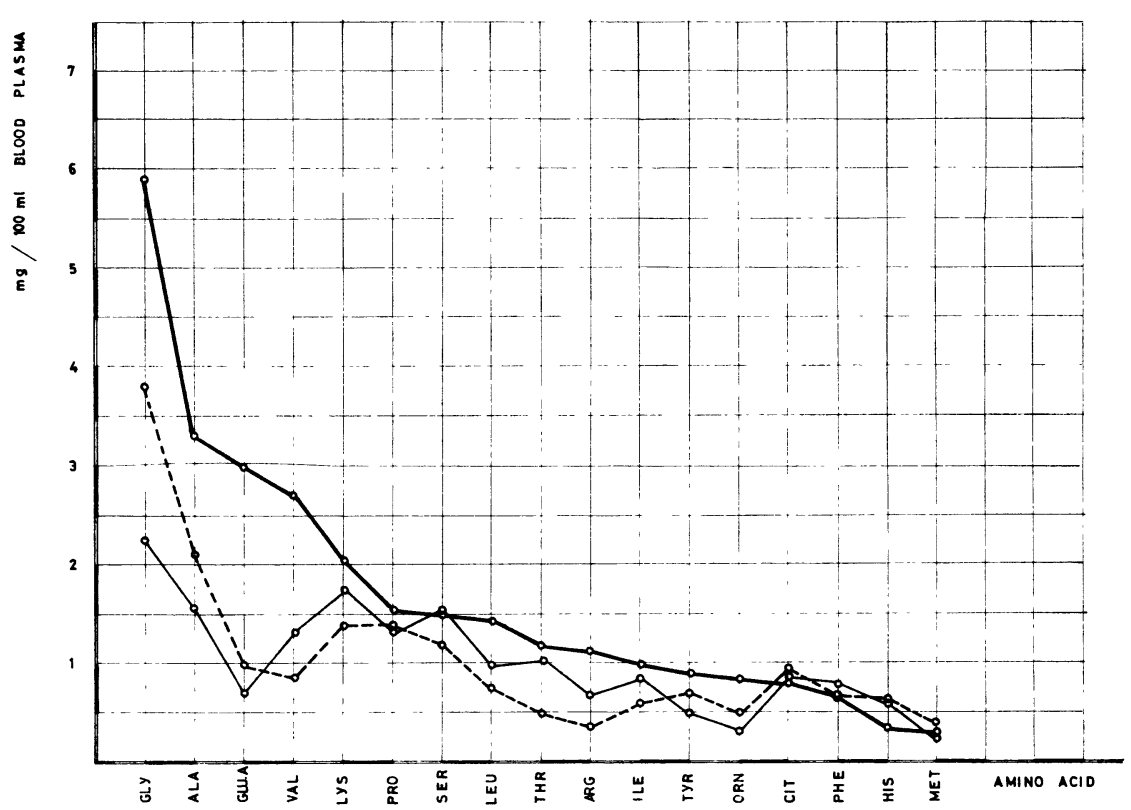

Figure 3. Free amino acids in the blood plasma of pigs during protein deficiency (cf. Fig. 1).

\section{DISCUSSION}

In a discussion about the effects of protein starvation, rehabilitation, and total starvation the branched chain amino acids merit special attention. Under conditions of protein deficiency the pigs showed very low plasma concentrations of leucine, isoleucine and valine whereas total starvation was accompanied by a large increase in their plasma levels. Holt et al. (1963, 1968) and Saunders et al. (1967) found that the levels of these amino acids decreased in all cases of kwashiorkor and the results of Swendseid et al. (1966), Luyken et al. (1966) and Young \& Scrimshaw (1968) support these findings.

Since during total starvation a very intensive deamination of amino acids is performed in the liver in order to supply energy, an accumulation of those amino acids, which are not oxidized there, is to be expected. Thus, Mimura et al. (1968) found that the activities of common branched chain amino acid transaminases are high in muscles but very low in liver. Moreover, perfused livers very slowly oxidize these amino acids (Miller 1962, McMenamy et al. 1962) and normally their concentrations 
T a ble 5. Free amino acids in the blood plasma of pigs during total starvation.

\begin{tabular}{lccr}
\hline \multirow{2}{*}{ Amino acids } & \multicolumn{3}{c}{ Starvation (days) } \\
\cline { 2 - 4 } & 0 & 14 & 23 \\
\hline threonine & 0.94 & 2.09 & 2.86 \\
valine & 2.88 & 4.45 & 4.23 \\
methionine & 0.28 & 0.74 & 0.72 \\
isoleucine & 1.03 & 1.66 & 2.24 \\
leucine & 1.36 & 1.82 & 2.68 \\
phenylalanine & 0.55 & 1.44 & 1.52 \\
lysine & 2.10 & 2.32 & 2.50 \\
histidine & 0.50 & 0.60 & 0.73 \\
\hline total essential amino acids & 9.68 & 15.12 & 17.48 \\
\hline serine & 1.40 & 1.43 & 1.79 \\
proline & 1.90 & 1.64 & 1.22 \\
glutamic acid & 3.68 & 1.47 & 1.32 \\
citrulline & 0.79 & 1.73 & 1.51 \\
glycine & 5.31 & 3.76 & 3.89 \\
alanine & 3.16 & 1.96 & 1.55 \\
tyrosine & 0.75 & 0.93 & 0.95 \\
ornithine & 1.21 & 0.94 & -1.54 \\
arginine & 1.24 & 1.68 & 12.77 \\
\hline total non-essential amino acids & 19.34 & 15.54 & \\
\hline ratio of essential to & & & 1.38 \\
non-essential amino acids & 0.50 & 0.98 & \\
\hline
\end{tabular}

are higher in hepatic veins than in arteries (Elwyn 1968). The liver concentrations of leucine, isoleucine and valine (in $\mu \mathrm{M} / \mathrm{mg}$ DNA) were decreased after protein depletion in rats and even more after total starvation, whereas the levels in muscles were almost unchanged (Allison et al. 1963).

The high plasma levels of these amino acids during total starvation may increase the rate of insulin release (Fajans et al. 1967), which would lead to a faster accumulation of amino acids in the muscle cells (Scharff \& Wool 1966). However, no significant changes were noted in blood glucose levels after protein or total starvation during this experiment (unpublished results) and the possible effects of other hormones cannot be discounted. Thus, children with kwashiorkor showed an increased concentration of human growth hormone, which has been reported to 
T a b l e 6. Concentration of urea in the blood plasma of pigs fed a semisynthetic diet with and without a milk protein supplement and totally starved pigs.

\begin{tabular}{|c|c|c|c|c|c|c|c|c|}
\hline \multirow{2}{*}{$\begin{array}{l}\text { Group } \\
\text { (treatment) }\end{array}$} & & \multicolumn{7}{|c|}{ Duration of experiment (days) } \\
\hline & & 0 & 14 & 29 & 42 & 56 & 70 & 83 \\
\hline $\begin{array}{l}\text { A } \\
\text { (control) }\end{array}$ & & $4.65^{\star}$ & 8.45 & 7.65 & 9.50 & 10.90 & 9.25 & 11.79 \\
\hline $\begin{array}{l}\text { B } \\
\text { (rehabilitation) }\end{array}$ & & 4.29 & 1.00 & 0.90 & 0.80 & 3.07 & 3.90 & 9.51 \\
\hline $\begin{array}{l}\text { G } \\
\text { (protein starvation) }\end{array}$ & $\begin{array}{l}\text { pig no. } 3 \\
\text { pig no. } 13 \\
\text { pig no. } 17\end{array}$ & & & & & & $\begin{array}{l}1.44 \\
1.19 \\
1.68\end{array}$ & $\begin{array}{r}10.90 \\
3.40\end{array}$ \\
\hline & mean value & 4.30 & 1.03 & 0.90 & 0.95 & 1.40 & 1.56 & 7.15 \\
\hline $\begin{array}{l}\text { D } \\
\text { (total starvation) }\end{array}$ & & 4.62 & 17.50 & $23.38^{\star \star}$ & & & & \\
\hline
\end{tabular}

* mg urea/100 ml blood plasma.

* This value was taken after 23 days of total starvation.

decrease blood free amino acid concentrations after injection (Pimstone et al. 1967).

Threonine, which is a glucogenic amino acid, behaved in a similar way to the branched chain amino acids during protein deficiency and total starvation, whereas the concentration of serine remained rather constant. Bearing in mind the participation of serine in the synthesis of ethanolamine, choline, cystine and its utilization in other reactions, the stability of the plasma concentration indicates the existence of synthesis even during long term protein deficiency. Thus, Fallon et al. (1968) found that the activities of the enzymes 3-phosphoglycerate dehydrogenase and phosphoserine phosphatase, which are involved in one pathway of serine synthesis, were increased during protein deficiency in rats.

Plasma lysine concentrations were affected by the dietary conditions in a typical manner for essential amino acids, although the slight increases observed after total starvation may be a reflection of the reduced plasma volume indicated by the haematocrit data (Mihailović et al. 1967).

The small elevation of plasma histidine levels during the first period of protein starvation suggests an inhibition of some of the processes in which this amino acid is used. Conversely the low histidine levels during rehabilitation indicate the reverse. 
Control pigs showed increases of both phenylalanine and tyrosine, but the ratio between them remained constant $(0.7-$ 0.8 ). However, during total starvation, the ratio rose to 1.6 probably due to a reduction in the rate of oxidation of phenylalanine to tyrosine. The slight increase of tyrosine levels may be a consequence of a decrease in the rate of utilization and the reduced plasma volume. The phenylalanine tyrosine ratio also rose above 1.5 during protein deficiency. Lack of enzyme activity may be envisaged as a cause of the reduction of phenylalanine hydroxylation, although the fall in tyrosine levels indicates that the rate of utilization is not greatly affected because of the availability of energy. On rehabilitation a faster rate of phenylalanine hydroxylation was possible and the concentration of phenylalanine decreased, whereas that of tyrosine rose rapidly so that only after 42 days the levels of both amino acids were at control values.

Of the non-essential amino acids glutamic acid, glycine and alanine showed similar patterns of response to both types of dietary deficiency. The rates of fall of concentration were more rapid during total starvation than protein deficiency due to the consumption of these amino acids as an energy supply. Rehabilitation of the protein deprived pigs lead to sharp increases in concentration above control levels.

It is interesting that the concentration of citrulline which is not normally a dietary component was preserved during protein deficiency, while the concentration of its precursor arginine was diminished. In total starvation the concentrations of both of these amino acids were elevated as a consequence of the intensive catabolism of amino acids through the urea cycle. While after total starvation the plasma urea concentration was greatly increased, during protein deficiency it was often depressed almost below the limits of detection. This is the consequence of the tendency during protein deficiency to conserve the available supply of amino nitrogen. Thus, the excretion of nitrogen and catabolism of amino acids are rapidly reduced to very low levels during the first few days of protein deficit (Č́uperlović \& Stošić 1968).

During the last days of protein deficiency the animals consumed almost no food so that the symptoms of protein deficiency were followed by those similar to total starvation, which meant 
an increase in the essential free amino acids and urea in the blood plasma but to a smaller degree, however, in these nitrogen depleted pigs than in starved normal animals.

\section{ACKNOWLEDGMENTS}

The authors wish to thank Professor J. Moustgaard, Royal Veterinary and Agricultural University, Copenhagen, Denmark, for advice and helpful discussions and Zdenka Boban for skilled technical assistance.

\section{REFERENCES}

Allison, J. B., R. W. Wannemacher jr. \& W. L. Banks: Influence of dietary protein on protein biosynthesis in various tissues. Fed. Proc. 1963, 22, 1126-1130.

Cupperlović, M., M. Jovanović \& D. Stošić: Free amino acids in the blood plasma of pigs during total starvation. In Isotope Studies on the Nitrogen Chain. International Atomic Energy Agency, Vienna 1968, 193-208.

Čuperlović, $M . \&$ D. Stošić: Protein metabolism in monogastric animals connected with their requirements for essential limiting amino acids. Institute for Application of Nuclear Energy in Agriculture, Veterinary Medicine and Forestry, Zemun, Yugoslavia. Ann. rep. Project no. E-30-AH-6, 1968.

Elwyn, D. H.: Modification of plasma amino acids patterns by the liver. In Protein Nutrition and Free Amino Acid Patterns, ed. J. H. Leathem, Rutgers Univ. Press, New Brunswick, New Jersey 1968, 88-107.

Fajans, S. S., J. C. Floyd jr., R. F. Knopf \& J. W. Conn: Effect of amino acids and protein on insulin secretion in man. Recent Progr. Hormone Res. 1967, 23, 617-662.

Fallon, H. J., J. L. Davis \& R. A. Goyer: Effect of protein intake on tissue amino acid levels and the enzymes of serin biosynthesis in the rat. J. Nutr. 1968, 96, 220-226.

Holt, L. E., S. E. Snyderman, P. M. Norton, E. Roitman \& J. Finch: The plasma aminogram in kwashiorkor. Lancet 1963, II, 13431348.

Holt, L. E., S. E. Snyderman, P. M. Norton \& E. Roitman: The plasma aminogram as affected by protein intake. In Protein Nutrition and Free Amino Acid Patterns, ed. J. H. Leathem, Rutgers Univ. Press, New Brunswick, New Jersey 1968, 32-40.

Lindquist, B.: Hydrolysis of proteins for amino acid determination. In Methods for Determination of Amino Acid Composition of Milk Proteins, ed. K. Brunfeldt, Danish Institute of Protein Chemistry, Copenhagen 1966, 7-15.

Luyken, R., N. A. Pikaar, P. Slump, T. Dohle \& R. Schrender: Serum amino acids and low-protein diet. Lancet 1966, I, 1213. 
McMenamy, R. H., W. C. Shoemaker, J. E. Richmond \& D. Elwyn: Uptake and metabolism of amino acids by the dog liver perfused in situ. Amer. J. Physiol. 1962, 202, 407-414.

Mihailović, M., B. Nikolić, O. Pavlović, M. Vukotić, M. Cuuperlović \& D. Stosici: The effect of total starvation on body weight and some blood components. Yugosl. physiol. pharmacol. Acta 1967, $3,342-345$.

Miller, $L$. L.: The role of liver and nonhepatic tissues in the regulation of free amino acid levels in the blood. In Amino Acid Pools, ed. J. T. Holden, New York, Elsevier 1962, 708-721.

Mimura, T., C. Jamada \& Marian E. Swendseid: Influence of dietary protein levels and hydrocortisone administration on the branched-chain amino acid transaminase activity in rat tissues. J. Nutr. 1968, 95, 493-497.

Nikolić, J. A., M. Čuperlović \& D. Stošić: Some effects of protein deficiency in young growing pigs. I. The serum protein system. Acta vet. scand. $1969,10,382-401$.

Pimstone, B., G. Barbezat, J. D. L. Hansen \& P. Murray: Growth hormone and protein calorie malnutrition. Lancet 1967, II, 13331334.

Saunders, S. J., A. S. Truswell, G. O. Barbezat, W. Wittman \& J. D. L. Hansen: Plasma free amino acid pattern in protein calorie malnutrition. Lancet 1967, II, 795-797.

Scharf, R. \& J. G. Wool: Effect of diabetes on the concentration of amino acids in plasma and heart muscle of rats. Biochem. J. 1966, 99, 173-178.

Stein, W. H. \& S. Moore: The free amino acids of human blood plasma. J. biol. Chem. 1954, 211, 915-926.

Swendseid, M. E., S. G. Tuttle, W. S. Figueroa, D. Mulcare, A. J. Clark \& F. J. Massey: Plasma amino acid levels of men fed diets differing in protein content. Some observations with valine deficient diets. J. Nutr. 1966, 88, 239-248.

Whitehead, R. G.: Hydroxyproline creatinine ratio as an index of nutritional status and rate of growth. Lancet 1965, II, 567-570.

Widdowson, E. M. \& R. G. Whitehead: Plasma amino acid ratios and urinary hydroxyproline excretion in rats deficient in protein and calories. Nature (Lond.) 1966, 212, 683-686.

Young, V. R. \& N. S. Schrimshaw: Endogenous nitrogen metabolism and plasma free amino acids in young adults given a "proteinfree" diet. Brit. J. Nutr. 1968, 22, 9-20.

Zimmermann-Telschow, H.: Die Veränderung der freien Aminosäuren im Nüchernblut in Abhängigkeit von der Ernährung beim Menschen. 2. Ernährungsversuche mit Milchprotein. (Changes in free amino acids in fasting human blood in relation to diet. 2. Trials with milk protein). Nutr. et Dieta (Basel) 1965, 7, 37-50. 


\section{SUMMARY}

The influence of protein deficiency, rehabilitation and total starvation on the free amino acid levels in the blood plasma of pigs has been investigated. It was found that the concentration of most amino acids was reduced during protein deficiency. The levels of leucine, isoleucine and valine were diminished by the greatest proportion, followed by threonine, tyrosine and citrulline. During the first few weeks of protein deficiency the levels of lysine, histidine and arginine were slightly increased, but later decreased below control values. Concentrations of glycine and alanine were altered in a similar way except that the initial increase was much more pronounced. The concentrations of most of these amino acids returned to control levels after rehabilitation. Total starvation led to an increase in concentration of leucine, isoleucine, valine, threonine and to a smaller extent phenylalanine, lysine, citrulline and arginine. The concentration of glycine, alanine and glutamic acid were very much reduced. The level of urea in the circulation dropped reversibly during protein deficiency and increased very much during total starvation.

\section{SAMMENDRAG}

Nogle virkninger af proteinmangel hos voksende svin. II. Frie aminosyrer $i$ blodplasmaet.

Virkningen af proteinmangel, rehabilitering og total faste på indholdet af frie aminosyrer i svineplasmaet er unders $\phi$ gt. Koncentrationen af de fleste aminosyrer er nedsat under proteinmangel. St $\varnothing r s t$ reduktion blev fundet $i$ indholdet af leucin, isoleucin og valin efterfulgt af threonin, tyrosin og citrullin. Koncentrationen af lycin, histidin og arginin steg svagt $i$ de første uger af proteinmangeltilstanden, men senere faldt disse koncentrationer til under kontrolværdierne. Tilsvarende ændringer, men med en mere udtalt initial stigning, blev fundet for glycin og alanins vedkommende. Efter rehabiliteringen steg koncentrationen af de fleste af de ovennævnte aminosyrer til samme niveau som kontroldyrenes. Total faste medf $\varnothing$ rte koncentrationsstigning af leucin, isoleucin, valin og threonin, medens indholdet af phenylalanin, lysin, citrullin og arginin steg $i$ mindre grad. Indholdet af glycin, alanin og glutaminsyre var derimod stærkt reduceret. Plasmaurinstof faldt under proteinmangel og steg stærkt ved total faste. 